\title{
65 lat Instytutu Hematologii i Transfuzjologii - czterej wybitni ludzie, bez których nie byłoby tej historii
}

\author{
65 years of the Institute of Hematology \& Transfusion Medicine \\ — four outstanding personalities who made this history possible
}

„Kto chce zapalać innych, sam musi płonąć”

Ludwik Hirszfeld

Era współczesnego krwiodawstwa i krwiolecznictwa, a w dużej mierze - hematologii jako dziedziny klinicznej — rozpoczęła się w 1901 roku, w którym oznaczono podstawowe grupy krwi. Odkrycia dokonał austriacki lekarz patolog i immunolog Karl Landsteiner, za co otrzymał w 1930 roku Nagrodę Nobla. Na uroczystości wręczenia nagrody 10 grudnia 1930 roku Przewodniczący Komitetu Noblowskiego w wystąpieniu opisującym postęp badań nad grupami krwi wymieniał kilkakrotnie trzy postaci: Landsteinera, von Dungerna i Hirszfelda. Mimo że nie podzielił $z$ Landsteinerem nagrody Nobla, profesor Ludwik Hirszfeld nie nosił w sobie poczucia krzywdy, zaś o Laureacie pisał w swoich wspomnieniach $z$ wielkim uznaniem, stwierdzając, że po wielokroć zasłużył na tę nagrodę.

Przed II wojną światową i tuż po jej zakończeniu w krajach Europy Zachodniej przeważał system krwiodawstwa i krwiolecznictwa oparty na prywatnych agenturach i stowarzyszeniach krwiodawców powiązanych ze sobą siecią komercyjnych „Banków Krwi”. Odmiennie wyglądała sytuacja w Związku Socjalistycznych Republik Radzieckich (ZSRR), a następnie w krajach tak zwanego bloku wschodniego. W 1926 roku powstał Centralny Instytut Hematologii i Przetaczania Krwi im. Orderu Lenina w Moskwie, w 1932 roku — Leningradzki Instytut Hematologii i Przetaczania Krwi, a kilka lat później stworzono już publiczną służbę krwi, która działała na obszarze całego ZSRR. We wszystkich stolicach republik związkowych i w większych miastach powstały instytuty konserwowania i przetaczania krwi, z podległymi sobie filiami, którymi były stacje przetaczania i konserwowania krwi w miastach obwodowych oraz punkty krwiodawstwa i przetaczania krwi w miastach rejonowych i mniejszych.
Krwiodawstwo było dobrowolne, stanowiąc „honorowy obowiązek społeczny obywatela". Podobny system publicznej służby krwi zaczęto wprowadzać w krajach zależnych od ZSRR i z całą mocą należy podkreślić, że akurat $\mathrm{w}$ tym przypadku zaproponowane rozwiązania miały wartość ponadczasową, a podwaliny systemu stworzone kilkadziesiąt lat temu służą do dziś.

\section{Ludwik Hirszfeld}

Przed zorganizowaniem publicznej służby krwi w Polsce to właśnie dzięki wielkiemu zaangażowaniu naukowemu i organizacyjnemu Profesora Ludwika Hirszfelda w latach 30. XX wieku powstawały pierwsze ośrodki krwiodawstwa. Jako przewodniczący Rady Naukowej Polskiego Czerwonego Krzyża (PCK) domagał się wydania zaleceń w zakresie obowiązujących badań wykonywanych u biorców i dawców. W 1935 roku PCK utworzyło pierwszy Ośrodek Przetaczania Krwi w Łodzi, a w 1936 roku otwarto Ośrodek Przetaczania Krwi w Warszawie. Kolejne ośrodki zaczęly powstawać dopiero po wojnie. W 1946 roku czynne były trzy ośrodki przetaczania krwi, w 1947 roku — cztery, w 1948 roku — osiem, w 1949 roku — czternaście. Ponadto terenowe jednostki organizacyjne krwiodawstwa podzielono na wojewódzkie stacje przetaczania i konserwowania krwi, powiatowe stacje przetaczania i konserwowania krwi oraz punkty krwiodawstwa.

Mimo powstawania coraz liczniejszych stacji krwiodawstwa, wydawania kolejnych instrukcji i rozporządzeń oraz prowadzenia licznych akcji szkoleniowych w środowisku lekarskim wciąż panowała nieufność wobec stosowania krwi konserwowanej 
i powszechnie stosowano krew świeżą, przetaczaną bezpośrednio $z$,żyły do żyły”, a nawet „pośrednio”. Tak o tych problemach pisał profesor Hirszfeld: PCK organizowat kursy, nieznajomość jednak piśmiennictwa z czasów ostatniej wojny czynita, że kursy te bynajmniej nie oddawaty wspótczesnego stanu krwiodawstwa. Dlatego zaproponowatem urzadzenie zjazdu transfuzji krwi, proponujac, by referaty programowe wygtoszone przez poszczególnych naukowców mogty stuzyć jako encyklopedia wspótczesnego krwiodawstwa. Zarzad PCK poczatkowo zgodzit sie na urzadzenie takiego zjazdu przez Rade Naukowa, później jednak cofnat udzielone mi petnomocnictwo. Zjazd mogtem zorganizować dopiero znacznie póziniej, w ramach Towarzystwa Hematologów.

W dniu 9 października 1949 roku w Krakowie odbył się organizacyjny Zjazd Polskiego Towarzystwa Hematologicznego (PTH); zadaniem było zorganizowanie Walnego Zgromadzenia i przeprowadzenie wyborów władz. W dniach 28-30 maja 1950 roku odbył się w Krakowie I Zjazd PTH, na którym powołano Zarząd Główny, a profesorowi Ludwikowi Hirszfeldowi nadano tytuł Honorowego Przewodniczącego (ryc. 1). W Zjeździe uczestniczyli między innymi naczelny hematolog ZSRR, a zarazem dyrektor Centralnego Instytutu Hematologii i Przetaczania Krwi im. Orderu Lenina w Moskwie, profesor A.A. Bagdasarow oraz dyrektor Leningradzkiego Instytutu Hematologii i Przetaczania Krwi docent A.A. Kisielew. Co ważne, Zjazd uchwalił dwie rezolucje - w pierwszej zalecano stosowanie w lecznictwie krwi konserwowanej, uznanej za pełnowartościową metodę leczenia, a w drugiej apelowano o utworzenie Instytutu Hematologii w Warszawie.

Minister zdrowia powołał organizacyjnie Instytut Hematologii 1 stycznia 1951 roku. Prawnie Instytut powołano do życia rozporządzeniem Prezydium Rady Ministrów z 2 czerwca 1951 roku i ustawą w Dzienniku Ustaw Rzeczpospolitej Polskiej nr A-61 z 16 lipca 1951 roku. W dniu 4 października 1951 roku miało miejsce pierwsze posiedzenie Rady Naukowej Instytutu Hematologii, w trakcie kolejnego natomiast profesor Ludwik Hirszfeld został jednogłośnie wybrany na jej Przewodniczącego.

W pierwszych 2 latach istnienia Instytutu Hematologii zreorganizowano istniejące stacje krwiodawstwa i utworzono nowe - wojewódzkie stacje krwiodawstwa. W 1951 roku Instytut opracował i wydał pierwsze przepisy pt. „Konserwowanie i przetaczanie krwi" pod redakcją docenta Artura Hausmana (PZWL; 1951). Redaktorami kolejnych wydań byli: Wanda Ostrowska („Pobierania, konserwowanie i przetwarzania krwi”, 1964), Wanda Ostrowska, Maria Przybyszewska-Artzt

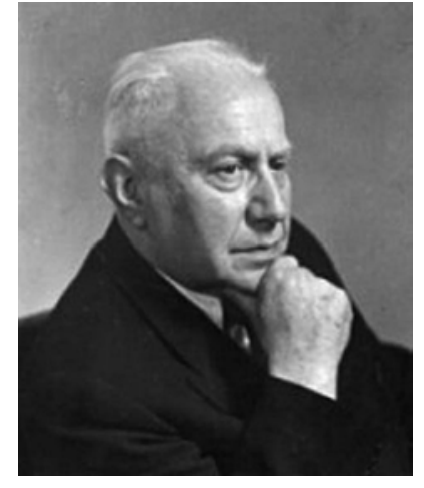

Rycina 1. Profesor Ludwik Hirszfeld - pierwszy Przewodniczący Rady Naukowej Instytutu Hematologii (1952-1953) i Honorowy Przewodniczący Zarządu Głównego Polskiego Towarzystwa Hematologicznego (1950-1954)

i Marzanna Kawecka („Przepisy dla stacji i punktów krwiodawstwa dotyczące wytwarzania krwi i preparatów krwiopochodnych”, 1974 i 1987), Jan Sablinski i Magdalena Łętowska („Krwiodawstwo. Zbiór przepisów dla placówek służby krwi”, Warszawa 1996 i „Krwiodawstwo i krwiolecznictwo. Zbiór przepisów”, Warszawa 2000) oraz Magdalena Łętowska (,,Medyczne zasady pobierania krwi, oddzielania jej składników i wydawania obowiązujące $\mathrm{w}$ jednostkach organizacyjnych publicznej służby krwi”, Warszawa 2006, 2011 i 2014).

We wspomnieniu o profesorze Hirszfeldzie, wygłoszonym w trakcie posiedzenia Rady Naukowej Instytutu Hematologii 20 marca 1954 roku przez doktor Irenę Lille-Szyszkowicz — wychowankę Profesora i pionierkę immunohematologii i hematologii dziecięcej w Polsce oraz założycielkę i pierwszą kierownik Zakładu Serologii w Instytucie Hematologii — prelegentka podkreśliła, że prawdy naukowe, które znalazty wyraz w pracach profesora Hirszfelda, staty sie podstawa dla rozwoju Polskiej Stużby Krwi (...). Kroczac droga wskazana przez tego Wielkiego Uczonego, serolodzy Polskiej Stużby Krwi dotoża wszelkich starań, by zdobycze naukowe, które zostawit, byty nadal wprowadzane w życie dla dobra cztowieka, któremu poświęcit On caty swój wielki umyst $i$ szerokie serce.

W hołdzie dla wybitnych zasług profesora Hirszfelda w dziedzinie krwiodawstwa i krwiolecznictwa w kraju i na świecie, w tym także roli, jaką odegrał w powstaniu Instytutu Hematologii i zapoczątkowaniu jego działalności, Rada Naukowa Instytutu Hematologii i Transfuzjologii na posiedzeniu 27 czerwca 2016 roku — będącego częścią obchodów jubileuszu 65 lat istnienia Instytutu — podjęła uchwałę w sprawie nadania sali posiedzeń Rady Naukowej Instytutu Hematologii i Transfuzjologii imienia Profesora Ludwika Hirszfelda. 


\section{Włodzimierz Ławkowicz}

Szczególnie dalekowzroczne w założeniach okazały się struktura i zadania statutowe nowo powstałego Instytutu Hematologii. W kolejnych latach ewoluowały one jedynie w zakresie nowych technologii medycznych, nazewnictwa i podległości organizacyjnej poszczególnych jednostek.

Na okres od 7 kwietnia do 19 maja 1951 roku Ministerstwo Zdrowia wydelegowało do Moskwy 8-osobową grupę specjalistów, złożoną z pełnomocnika ministra zdrowia do spraw organizacji Instytutu Hematologii (doc. Artura Hausmana) oraz przyszłych pracowników Instytutu Hematologii (w tym dr. Włodzimierza Ławkowicza) do zapoznania się $z$ organizacją Centralnego Instytutu Hematologii i Przetaczania Krwi. W ciągu 6-tygodniowego pobytu delegaci zapoznali się $z$ organizacją służby krwiodawstwa, technikami pobierania i konserwowania krwi oraz przygotowywania osocza, surowicy i innych produktów krwiopochodnych. Umożliwiono także zwiedzenie działu klinicznego wraz z zapleczem laboratoryjnym. O tych doświadczeniach tak pisał w 1951 roku doktor Ławkowicz na łamach „Polskiego Tygodnika Lekarskiego”: wcielenie w obrę Instytutu 3 klinik, $w$ tym hematologicznej, wewnętrznej i chirurgicznej, nie byto dzietem przypadku, lecz zostato podyktowane przez zycie. Umożliwia ono bowiem prowadzenie jednolitych badań $w$ zakresie hemoterapii w chorobach wewnetrznych, chirurgicznych i uktadu krwiotwórczego oraz opracowanie $i$ ulepszanie nowoczesnych metod leczenia chirurgicznego (splenektomia) niektórych chorób hematologicznych (...). Jakkolwiek przypadki hematologiczne prowadzone sa zwykle w oddziatach wewnętrznych, jako wchodzace w zakres kompetencji internisty, tózka hematologiczne $w$ moskiewskim Instytucie sq wydzielone w odrębny oddziat. I pod tym wzgledem moskiewska klinika jest pionierska w skali światowej. W ostatnich dopiero latach przyktad ten znalazt naśladownictwo we Francji, gdzie stworzono klinike hematologiczna $w$ Paryzu, kierowana przez profesora P. Chevaliera. Doświadczenie wykazato bowiem, że przypadki chorób uktadu krwiotwórczego wymagaja opieki wysoko kwalifikowanych specjalistów. Trzecią taką kliniką w Europie i pierwszą w Polsce była Klinika Hematologiczna utworzona i kierowana w latach 1951-1977 przez Włodzimierza Ławkowicza w Instytucie Hematologii (ryc. 2).

Przed rozpoczęciem pracy w Instytucie Hematologii, a po ukończeniu studiów na Wydziale Lekarskim Uniwersytetu Warszawskiego w 1935 roku, doktor Ławkowicz rozpoczął pracę kliniczną na Oddziale Wewnętrznym Szpitala Wolskiego i jed-

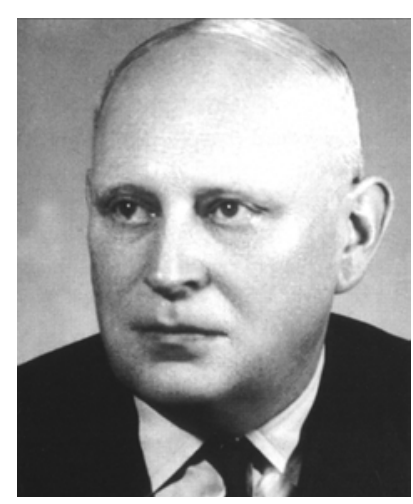

Rycina 2. Profesor Włodzimierz Ławkowicz — założyciel i wieloletni kierownik Kliniki Hematologicznej (1951-1977)

nocześnie prowadził prace naukowe nad riketsjami i niedokrwistością zakaźną (Bartonella muris) w Dziale Bakteriologii i Medycyny Doświadczalnej kierowanym przez profesora Hirszfelda w Państwowym Zakładzie Higieny. To $z$ tego okresu pochodzą również pionierskie badania zespołu badaczy pod kierunkiem profesora Hirszfelda nad odrębnością antygenową tkanki nowotworowej i zagadnieniem postaci przejściowych grup krwi. Po wojnie doktor Ławkowicz był także konsultantem hematologicznym i kierownikiem Pracowni Analitycznej w Instytucie Radowym w Warszawie

Ważną publikacją $z$ tego okresu jest opisany przez Ławkowicza, Włodarskiego i Gewonta pierwszy na świecie przypadek u osoby dorosłej atypowej postaci ostrej szpikowicy czerwonokrwinkowej o cechach nowotworowych (Pol. Arch. Med. Wew. 1951; 21: 2-3), w którym wskazano na prawdopodobny nowotworowy charakter proerytroblastomy oraz innych białaczek. Ponadto doktor Ławkowicz jako pierwszy wykazał wpływ czynników humoralnych na granulopoezę i limfopoezę (Arch. Immunol. Ther. Exp. 1955; 3: 289). Była to najpewniej pierwsza praca dokumentująca udział krwiotwórczych czynników wzrostu i cytokin w patogenezie przewlekłej białaczki szpikowej i przewlekłej białaczki limfocytowej.

Wielkim sukcesem w kraju i za granicą był „Atlas hematologiczny oraz wytyczne w rozpoznawaniu chorób układu krwiotwórczego" - pierwszy atlas hematologiczny wydany w Polsce, oparty na materiale własnym profesora Ławkowicza, do którego ryciny wykonała Jego żona — doktor Izabela Krzemińska-Ławkowicz (PZWL; 1952). Wspólnie z żoną profesor Ławkowicz opracował 19 wydawnictw książkowych, tłumaczonych na wiele języków, w tym rosyjski, czeski, angielski, francuski i niemiecki. „Diagnostyka hematologiczna” 
(PZWL; 1960) uzyskała miano książki medycznej XV-lecia; jej wznowione i uzupełnione wydanie pt. „Kliniczna diagnostyka różnicowa w hematologii” (PZWL; 1965, 1971, 1973 i 1982), a także „Hematologia wieku dziecięcego" (PZWL; 1962 i 1969) stanowiły przez następnych 25 lat podstawowe podręczniki do nauki interny, pediatrii i hematologii dla studentów medycyny i lekarzy.

Instytut Hematologii stał się w tym czasie prawdziwą kuźnią specjalistów w zakresie hematologii, w czym pomogło również sprawowanie przez profesora Ławkowicza funkcji kierownika powołanej tu w 1960 roku Katedry Hematologii Studium Doskonalenia Lekarzy (SDL). Profesor Ławkowicz kierował Katedrą Hematologii SDL do 1971 roku, a po jej reorganizacji i przekształceniu w Centrum Medyczne Kształcenia Podyplomowego sprawował funkcję kierownika Kliniki Hematologicznej w Instytucie aż do czasu przejścia na emeryturę (30.11.1977 r.). Nadto profesor Ławkowicz, wraz $z$ innymi Pracownikami Instytutu, był jednym $z$ inicjatorów założenia pierwszego ogólnopolskiego pisma hematologicznego, wydawanego przez Instytut Hematologii wspólnie z PTH - „Acta Haematologica Polonica”.

Klinika Hematologiczna kierowana przez profesora Ławkowicza była nie tylko oddziałem klinicznym, ale przede wszystkim ,szkołą Ławkowicza” Jak pisali o niej w „Biuletynie Głównej Biblioteki Lekarskiej” w 1962 roku jej Pracownicy: szkota ta oparta byta na wysoko wyspecjalizowanej i przeszkolonej odpowiednio kadrze naukowo-dydaktycznej $w$ zakresie hematologii klinicznej, transfuzjologii, immunohematologii, koagulologii, cytomorfologii, cytochemii, cytoenzymologii, cytogenetyki, hodowli tkanek, biochemii hematologicznej $i$ patofizjologii biatek krwi. Profesor Ławkowicz zorganizował dla tych dyscyplin odpowiednią bazę laboratoryjną, zaplecze naukowo-badawcze i dydaktyczne. To osiągnięcie nie miało precedensu w ówczesnej polskiej hematologii.

W hołdzie dla pionierskich zasług profesora Włodzimierza Ławkowicza dla powstania i rozwoju Instytutu Hematologii, a także dokonań naukowych i dydaktycznych w dziedzinie hematologii, poczynionych przede wszystkim we współpracy z żoną - profesor Izabelą Krzemińską-Ławkowicz - 27 czerwca 2016 roku Rada Naukowa Instytutu Hematologii i Transfuzjologii podjęła uchwałę w sprawie nadania sali seminaryjnej Kliniki Hematologii imienia Profesora Włodzimierza Ławkowicza i Profesor Izabeli Krzemińskiej-Ławkowicz.

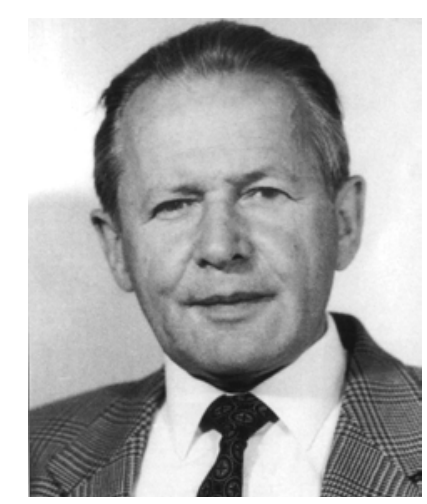

Rycina 3. Profesor Stanisław Łopaciuk - kierownik Pracowni Biochemii Klinicznej przy Klinice Chorób Wewnętrznych (1968-1983), a następnie utworzonej z niej Samodzielnej Pracowni Krzepnięcia Krwi i Hemostazy (1983-2003)

\section{Stanisław Kopaciuk}

Klinika Chorób Wewnętrznych — podobnie jak Klinika Hematologiczna - również powstała $z$ chwilą powołania Instytutu Hematologii. Jej kierownictwo powierzono docentowi Edwardowi Kowalskiemu, którego gruntowna znajomość chemii w połączeniu $z$ doświadczeniem klinicznym pozwoliły na utworzenie przy klinice Pracowni Biochemii Klinicznej. W tej Pracowni zespół kierowany przez doktora Niewiarowskiego zapoczątkował prace naukowe i kliniczne dotyczące krzepnięcia krwi, fibrynolizy i metabolizmu zelaza (Thromb. Diath. Haemorrh. 1959 i Am. J. Physiol. 1959). W 1958 roku Niewiarowski i wsp. opublikowali wyniki pierwszego badania nad występowaniem hemofilii A i B w Polsce (Pol. Tyg. Lek. 1958; 13: 2101).

W 1966 roku zespół lekarzy Kliniki Chorób Wewnętrznych, do którego należał doktor Stanisław Łopaciuk (ryc. 3), podjął pierwszą w Polsce i jedną $z$ pierwszych na świecie próbę trombolitycznego leczenia zawału serca za pomocą wlewu streptokinazy i wykazał, że leczenie to wdrożone w pierwszych 12 godzinach dokonanego zawału przynosi korzyści w postaci zmniejszenia obszaru martwicy mięśnia sercowego.

W latach 1968-1969 doktor Łopaciuk - już jako kierownik Pracowni Biochemii Klinicznej przy Klinice Chorób Wewnętrznych - rozwinął produkcję krioprecypitatu, a następnie opracował metodę otrzymywania koncentratu czynnika VIII (Acta Haematol. Pol. 1971; 2: 103) i czynnika IX (Acta Haematol. Pol. 1978; 9: 107). Wytwarzanie koncentratów czynników VIII i IX w stacjach krwiodawstwa oraz ich powszechne stosowanie 
u chorych na hemofilię A i B pozwoliło ograniczyć import zachodnich koncentratów czynników krzepnięcia, a tym samym uchroniło chorych w Polsce przed powszechnym zakażeniem HIV, które miało miejsce w Europie Zachodniej i Ameryce Północnej w tym okresie.

Specyfika i zakres badań prowadzonych w tym czasie przez profesora Łopaciuka i jego zespó1 zaczęły istotnie wykraczać poza spektrum zainteresowań naukowych Kliniki Chorób Wewnętrznych, w tym także poza możliwości organizacyjne i funkcjonalne pracowni przyklinicznej. Fakt ten zdecydował o wydzieleniu tej Pracowni ze struktur Kliniki i utworzeniu w 1983 roku Samodzielnej Pracowni Krzepnięcia Krwi i Hemostazy. Od połowy lat 80. XX wieku zespół tej Pracowni rozpoczął badania nad wrodzoną trombofilią, co zaowocowało między innymi ustaleniem częstości występowania mutacji Leiden genu czynnika V (Genet. Epidemiol. 1997; 14: 403) i mutacji G20210A genu protrombiny w Polsce (Pol. Arch. Med. Wewn. 2000; 104: 792). Ustalono między innymi, że proteazy ludzkich granulocytów różnie działają na powierzchniowe glikoproteiny zależnie od stanu czynnościowego płytek, trawią i niszczą aktywność czynnika VIII oraz czynnika von Willebranda.

Lata 90. XX wieku przyniosły publikacje poświęcone leczeniu chorych na żylną chorobę zakrzepowo-zatorową, w których wykazano, że nadroparyna jest co najmniej tak samo skuteczna i bezpieczna jak heparyna niefrakcjonowana w leczeniu ostrego epizodu choroby zakrzepowo-zatorowej (Thromb. Haemost. 1992) oraz że nadroparyna stosowana w połowicznej dawce terapeutycznej jest skuteczną i bezpieczną alternatywą dla antagonisty witaminy $\mathrm{K}$ we wtórnej profilaktyce (Thromb. Haemost. 1999). Wybitnym osiągnięciem edukacyjnym profesora Łopaciuka $z$ tego okresu był podręcznik wydany pod Jego redakcją pt. „Zakrzepy i zatory” (PZWL; 1996 i 2002).

W hołdzie dla dorobku naukowego i dydaktycznego profesora Stanisława Łopaciuka w dziedzinie hemostazy, a także dokonań organizacyjnych dla rozwoju Instytutu Hematologii i stworzenia kompleksowej opieki nad chorymi na wrodzone skazy krwotoczne w Polsce, 27 czerwca 2016 roku Rada Naukowa Instytutu Hematologii i Transfuzjologii podjęła uchwałę w sprawie nadania sali seminaryjnej Kliniki Zaburzeń Hemostazy i Chorób Wewnętrznych imienia Profesora Stanisława Łopaciuka.

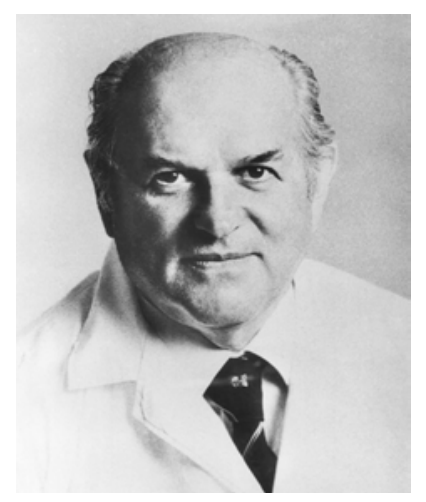

Rycina 4. Profesor Witold Rudowski - Dyrektor Instytutu Hematologii i kierownik Kliniki Chirurgicznej (1964-1988)

\section{Witold Rudowski}

Trzecią kliniką powstałą z chwilą powołania Instytutu Hematologii była Klinika Chirurgiczna, która poza rutynową działalnością usługową zajmowała się także kompleksowym leczeniem oparzeń i wstrząsu. To tu był pierwszy oddział w Polsce, na którym metody ich leczenia oparto na nawadnianiu chorych płynami infuzyjnymi, osoczem i środkami krwiozastępczymi. Na podstawie ogromnego doświadczenia własnego, wynikającego $z$ leczenia ponad 2000 oparzonych chorych, zespół Kliniki Chirurgicznej przeprowadził pionierskie wówczas badania nad miejscowym leczeniem ran oparzeniowych $z$ zastosowaniem autologicznych siatkowych przeszczepień skóry. Przeprowadzano również badania nad wczesnym wycinaniem oparzeń i zastosowaniem przeszczepień skóry wieprzowej i „sztucznej” skóry na rany oparzeniowe. Zespół Kliniki wydał też pierwszą w Polsce monografię na temat oparzeń, pt. „Oparzenia jako problem badawczy i leczniczy” pod redakcją Witolda Rudowskiego i wsp., która miała cztery polskie wydania, a także wydania angielskie (Burn Therapy and Research. Baltimore, 1976) i rosyjskie. Ponadto w Klinice Chirurgicznej przeszkolono kilka tysięcy lekarzy z całego kraju — wśród nich również dyrektora nowo powstałego i istniejącego do dziś ośrodka leczenia oparzeń w Siemianowicach.

Powstanie referencyjnego ośrodka ds. oparzeń na Śląsku oraz niedostateczna przestrzeń lokalowa Kliniki Chirurgicznej w siedzibie przy ul. Chocimskiej $5 \mathrm{w}$ Warszawie spowodowały zamknięcie oddziału oparzeń w Instytucie i przeprofilowanie dotychczasowej aktywności na zagadnienia dotyczące zaburzeń hemostatycznych. Dokonał tego wieloletni kierownik Kliniki i dyrektor Instytutu — Profesor Witold Rudowski (ryc. 4). 
Zespół Kliniki pod kierunkiem profesora Rudowskiego opracował i wdrożył do praktyki klinicznej zasady bezpiecznego leczenia operacyjnego $\mathrm{u}$ chorych $\mathrm{z}$ wrodzonymi niedoborami osoczowych czynników krzepnięcia. Począwszy od pionierskiej w Polsce operacji brzusznej u chorego na hemofilię w 1966 roku, w miarę nabywania doświadczeń, udoskonalano technikę operacji, sposoby postępowania przed- i pooperacyjnego, zwłaszcza stosowania terapii substytucyjnej, początkowo przy użyciu krioprecypitatu, a następnie $z$ wykorzystaniem koncentratów niedoborowych czynników krzepnięcia; opisano je w monografii pod redakcją profesora Rudowskiego pt.: ,Zaburzenia hemostazy w chirurgii" (PZWL; 1971). Unowocześnione wydanie tej monografii, zatytułowane Disorders in Hemostasis in Surgery zostało opublikowane w 1977 roku przez University Press of New England (New Hampshire).

$\mathrm{W}$ oparciu o jeden $\mathrm{z}$ największych $\mathrm{w}$ świecie materiał kliniczny, obejmujący kilkuset operowanych chorych $z$ hemofilią A i B, chorobą von Willebranda i innymi rzadkimi skazami krwotocznymi, zespół kierowany przez profesora Rudowskiego opublikował wiele znaczących prac dokumentujących bezpieczeństwo leczenia operacyjnego chorych na hemofilię, w tym zaliczane do mile-stone opracowanie pt. Is major of surgery in hemophiliac patients safe opublikowane w ,World Journal of Surgery” w 1987 roku. W kolejnych latach, jako jedyny ośrodek w kraju, zespół Kliniki rozpoczął operacje chirurgiczne u chorych na hemofilię, wykonując ich kilkudziesiąt rocznie. W likwidacji kalectwa ruchowego duże znaczenie miały zwłaszcza zabiegi chirurgiczne wszczepienia protez stawowych oraz synowektomia z zastosowaniem izotopów promieniotwórczych.

W 1975 roku zespół Kliniki kierowanej przez profesora Rudowskiego jako pierwszy w Polsce wykonał zabieg endoskopowej skleroterapii żylaków przełyku, która na dziesięciolecia stała się „Złotym standardem” leczenia stosowanego u tych chorych. Do osiągnięć w badaniach nad nadciśnieniem wrotnym należało także opracowanie zasad wtórnej profilaktyki krwawień z żylaków przełyku metodą powtarzanej skleroterapii. Do innych osiągnięć zaliczają się pionierskie prace nad zastosowaniem endoskopowej terapii iniekcyjnej w leczeniu krwawień $z$ wrzodów trawiennych i innych zmian w obrębie przewodu pokarmowego. Do znaczących osiągnięć należało również opracowanie zasad chirurgii śledziony, w tym wskazań do splenektomii oraz postępowania przed- i pooperacyjnego, opublikowanych w monografii pt. „Chirurgia śledziony” pod redakcją Rudowskiego i Pawelskiego (PZWL, 1982 i Surgery of the spleen, 1987).
W latach 80. XX wieku jednym $z$ głównych tematów badawczych zespołu kierowanego przez profesora Rudowskiego było rozpoznawanie, profilaktyka i leczenie żylnej choroby zakrzepowo-zatorowej. Opracowano zasady trombektomii żylnej z założeniem czasowej przetoki tętniczo-żylnej w leczeniu ostrej proksymalnej zakrzepicy żył głębokich kończyn dolnych, a technikę operacji i wyniki opublikowano w ,World Journal of Surgery” w 1987 roku. W dalszych badaniach koncentrowano się na opracowaniu standardów wykonywania badań flebograficznych i ultrasonograficznych układu żył kończyn dolnych i miednicy, optymalnych metod zachowawczego i chirurgicznego leczenia zakrzepicy żył głębokich i powierzchownych kończyn dolnych i górnych, udoskonalaniu metod zapobiegania zakrzepicy żył głębokich kończyny dolnych, a także optymalizacji leczenia farmakologicznego i chirurgicznego powikłań spowodowanych przewlekłą chorobą żylną i zespołem pozakrzepowym. Ocena wyników leczenia zakrzepic żył głębokich dużymi dawkami leków trombolitycznych opublikowana w „British Journal of Surgery” (skrót ukazał się w „,Year Book of Vascular Surgery” w 1989 r.) przyczyniła się do zarzucenia tej metody leczenia zakrzepic żylnych w świecie.

Zespół Kliniki Chirurgicznej kierowanej przez profesora Rudowskiego przeprowadził także wiele badań doświadczalnych i klinicznych nad przetoczeniami krwi przechowywanej w niskich temperaturach oraz nad zastosowaniem hemoglobiny pozbawionej zrębu komórkowego i hydroksyetylowanej skrobi u zwierząt doświadczalnych. Efektem tych badań było między innymi wdrożenie do stosowania klinicznego płynów osoczozastępczych — dekstranu nisko- i średniocząsteczkowego oraz roztworów żelatyn — jak również przeprowadzenie pierwszej w Polsce przedoperacyjnej normowolemicznej hemodylucji śródoperacyjnej. Doświadczenia te zaowocowały licznymi monografiami i podręcznikami, takimi jak: „Powikłania po przetoczeniu krwi i środków krwiopochodnych” (Sabliński i Scharf, 1962), „Transfuzjologia kliniczna” (Rudowski i Pawelski, 1971), „Wstrząs, patogeneza i leczenie” (Rudowski i wsp., 1972), „Objętość krwi krążącej. Wstrząs, operacja, znieczulenie" (Zienkiewicz, 1976), „Współczesna transfuzjologia” (Rudowski i Pawelski, 1985).

Poza osiągnięciami krajowymi profesor Rudowski miał ogromne zasługi $\mathrm{w}$ reprezentowaniu Instytutu Hematologii i polskiej chirurgii na arenie międzynarodowej jako ekspert Światowej Organizacji Zdrowia, a także wieloletni przewodniczący, a potem członek Zarządu Międzynarodowego Towarzystwa 
Chirurgicznego. Należy również przypomnieć, że od 1956 roku przez 18 lat pełnił funkcję redaktora naczelnego „Nowotworów” — organu Polskiego Towarzystwa Onkologicznego i Instytutu Onkologii im. Marii Skłodowskiej-Curie, a także przez wiele lat był sekretarzem naukowym w tej instytucji.

Jako dyrektor Instytutu Hematologii podjął się wielu cennych inicjatyw organizacyjnych, w tym utworzenia w latach 60. XX wieku sekcji transfuzjologicznej PTH, której przewodniczącymi byli kolejno: On sam, a następnie profesor Halina Seyfried i profesor Magdalena Łętowska. W 1975 roku powołał w Instytucie Hematologii Krajowy Zespół Specjalistyczny do spraw transfuzjologii; w ciagu kolejnych 35 lat to właśnie w Instytucie prowadzili swoją działalność konsultanci krajowi w dziedzinie transfuzjologii klinicznej: Halina Seyfried, Jan Sabliński, Magdalena Łętowska, Ryszard Pogłód. Dzięki inicjatywie profesora Rudowskiego w latach 90. XX wieku PTH zmieniło nazwę na Polskie Towarzystwo Hematologów i Transfuzjologów. Wieloletnia działalność Instytutu Hematologii w zakresie krwiodawstwa i krwiolecznictwa była także podstawą zmiany jego nazwy w 1992 roku na Instytut Hematologii i Transfuzjologii.

W czasie 24-letniej pracy na stanowisku kierownika Kliniki Chirurgicznej i dyrektora Instytutu Hematologii profesor Rudowski stworzył atmosferę twórczej pracy naukowej i lekarskiej oraz wychował wielu wykwalifikowanych chirurgów, których można zaliczyć do „wysokiej klasy szkoły chirurgiczno-hematologiczno-transfuzjologicznej profesora Rudowskiego" - jak to określił w swoich wspomnieniach Jego wieloletni wspólpracownik profesor Slawomir Pawelski. W hołdzie dla tego ogromnego dorobku naukowego, dydaktycznego i organizacyjnego 27 czerwca 2016 roku Rada Naukowa Instytutu Hematologii i Transfuzjologii podjęła uchwałę w sprawie nadania sali seminaryjnej Kliniki Chirurgii Ogólnej, Onkologicznej i Metabolicznej oraz Kliniki Chirurgii Naczyniowej imienia Profesora Witolda Rudowskiego.

\section{Podsumowanie}

Sześćdziesiąciopięcioletnia historia Instytutu Hematologii i Transfuzjologii jest bardzo bogata i ciekawa. Przez cały ten czas Instytut konsekwentnie realizował zadania naukowe, usługowe, edukacyjne, aplikacyjne, a nawet produkcyjne, przyczyniając się do rozwoju wiedzy o krwiodawstwie i krwiolecznictwie, diagnostyce i leczeniu chorych na choroby krwi, a tym samym - do rozwoju polskiej transfuzjologii i hematologii.

Korzystając $z$ wiedzy i mądrości naszych Poprzedników, Nauczycieli i Wychowawców, w tym profesorów Hirszfelda, Ławkowicza, Łopaciuka i Rudowskiego, dziś kontynuujemy dzieło wcześniejszych pokoleń, które dzięki swoim wysiłkom pozostawiły trwały ślad w historii Instytutu Hematologii i Transfuzjologii i polskiej medycynie*.

prof. dr hab. n. med. Krzysztof Warzocha
Dyrektor Instytutu
Hematologii i Transfuzjologii

Adres do korespondencji: Krzysztof Warzocha, Klinika Hematologii, Instytut Hematologii i Transfuzjologii, ul. Indiry Gandhi 14, 02-776 Warszawa, e-mail: warzocha@ihit.waw.pl 